Article

\title{
An Empirical Study on Optimal Strategies of Industry-University-Institute Green Innovation with Subsidy
}

\author{
Wenqing Wu ${ }^{1,2}$, Kexin $\mathrm{Yu}^{1}$, Saixiang Ma ${ }^{1}$, Chien-Chi Chu ${ }^{3, *}{ }^{\mathbb{D}}$, Shijie $\mathrm{Li}^{4, *}$, Chengcheng Ma ${ }^{5, *}$ \\ and Sang-Bing Tsai $6,7, *$ (1) \\ 1 College of Management and Economics, Tianjin University, Tianjin 300072, China; \\ wenqingw@tju.edu.cn (W.W.); kionayu@163.com (K.Y.); sxma92@163.com (S.M.) \\ 2 Research Center for National Intellectual Property Strategy Implementation (TJU), Tianjin 300072, China \\ 3 Department of Finance, Business School of Shantou University, Shantou 515063, China \\ 4 School of Business Administration, Guangdong University of Finance and Economics, \\ Guangzhou 510320, China \\ 5 Business School, Nankai University, Tianjin 300071, China \\ 6 Zhongshan Institute, University of Electronic Science and Technology of China, Zhongshan 528400, China \\ 7 Research Center for Environment and Sustainable Development of China Civil Aviation, Civil Aviation \\ University of China, Tianjin 300300, China \\ * Correspondence: jqzhu@stu.edu.cn (C.-C.C.); 1shijie@foxmail.com (S.L.); orange_macc@163.com (C.M.); \\ sangbing@hotmail.com (S.-B.T.)
}

Received: 25 April 2018; Accepted: 14 May 2018; Published: 21 May 2018

\begin{abstract}
With the increasing awareness of environmental protection and the complexity and rapid change of technological innovation, more and more enterprises seek to develop and research (R\&D) institutions to cooperate with green innovation. In order to promote the cooperation efficiency of green innovation, this paper develops a multi-stage game model to analyze the optimal strategies of the enterprise, the university and the policy-maker with consumer learning and government subsidy. Then the paper compares the difference of optimal subsidy between the single-stage green innovation cooperation and the multi-stage green innovation cooperation. The research shows that consumers' initial learning factors and green innovation cooperation cycle have a significant impact on the optimal input level of the enterprise and the university and also have a significant impact on the optimal subsidy of the government. The specific government subsidy and subsidy ratio depend on the comprehensive role of consumer learning factors and the green innovation cooperation cycle. In the end, we propose that the government should subsidize the university at times when the initial consumer learning factor is low; the government subsidy should be properly lagged when the initial consumer learning factor is high.
\end{abstract}

Keywords: industry-university-institute cooperation; green innovation; consumer learning; government subsidy; game

\section{Introduction}

With the continuous reduction of the earth's natural resources and the continuous deterioration of the ecological environment, most countries in the world have adopted various measures to protect the environment. These countries set up relevant laws and regulations on environmental protection, raise the threshold of emissions and punish environmental damage behaviors more severely. Therefore, enterprises need to improve technology and make green products to attract consumers, occupy the 
market and increase the competitiveness. Green innovation has become a very important strategic tool for enterprises to carry out sustainable development.

At the same time, with the increasing awareness of environmental protection, the consumption demand of green products has become higher and higher. It is reported that more than half of consumers will pay more for green products [1]. The result is that products with green innovation will get more customers' attention and more sales. For example, the market share of the Prius in green conscious regions of the United States is significantly higher than the market share of equivalent cars like the Honda Accord Hybrid [2]. Therefore, more and more enterprises invest and develop green products. About $90 \%$ of Fortune 500 companies report to develop green products and a large number of green innovations have been created in Luo and $\mathrm{Du}$ [3].

With competition intensifying and consumer learning, technology updates accelerating and market environment changing rapidly, the life cycle of more and more products is becoming shorter. Companies seek cooperation for $\mathrm{R} \& \mathrm{D}$ to face the rapid change. Further, recent studies have provided sufficient facts which show that the sales of cooperative innovation products are not only affected by the coordination mechanism and the efforts of partners but also the consumer learning, especially the learning of the sales and evaluation of previous products from the network [4]. The consumer Bayesian learning process theory widely accepted believes that the consumer is uncertain about the quality of the product [5]. Based on the previous experience, the product quality is expected to be updated. Consumers' purchase of green innovative products is subject to the purchase experience (evaluation) and pre sales of the consumers who have bought the product. Senecal and Nantel [6] show that in the purchase of innovative products, consumers' purchase decisions depend on the consumption experience and initial sales volume of the products they have purchased. Therefore, consumer learning plays an important role in cooperation innovation of green product.

By the same token, with the complexity and rapid change of technological innovation, more and more institutions are cooperating with innovation. As an approach to improve innovation in the economy, the collaboration between universities and industry is becoming more and more common [7]. It is reported that these collaborations have been substantial increase including some countries such as the United States, Japan and European Union Countries [8-10]. On the other hand, due to the externalities of innovation and the greater risk of innovation, Hinloopen [11] argues that the government should subsidize R\&D. Through empirical analysis of 7 European countries, Franco et al. find that public subsidies have a positive impact on $R \& D$ cooperation.

There is a lot of literature focusing on coordination of green supply chain and the cooperative innovation contract between universities and industry [12-14]. However, very few researches have addressed the issue of optimal strategies of green innovation under the multi-stage cooperation. To the best of our knowledge, the optimal strategies of universities and industry when considering consumer learning and government subsidy simultaneously have not been addressed. In order to fill this gap, we address the following three questions in this paper.

(1) How the firm determines the optimal green technology investment strategies and cost sharing with customer learning and government subsidy?

(2) How the university determines the optimal green technology investment strategies with customer learning and government subsidy?

(3) How the government determines the optimal subsidy to promote the green innovation cooperation with customer learning.

The remainder of the paper is organized as follows. In Section 2, we start to summarize the extant literature including enterprise-university-research cooperative innovation, consumer learning in innovation cooperation and government support for innovation. We present modeling descriptions and assumptions in Section 3. Section 4 investigates the optimal green technology investment and cost sharing strategies of the firm with consumer learning and subsidy. The university's optimal green technology investments and optimal government subsidy are also analyzed. In Section 5, we analyze 
the characteristics of multi-stage green cooperation and single-stage green cooperation between firm and university. A numerical study is conducted and managerial insights are presented in Section 6 . In Section 7, we conclude our key findings and point out potential research directions.

\section{Literature Review}

Our study highly relates to several streams of literature including enterprise-university-research cooperative innovation, consumer learning in innovation cooperation and government support for innovation.

\subsection{Enterprise-University-Research Cooperative Innovation}

Many researchers discuss the cooperation problems in enterprise-university-research cooperative innovation $[15,16]$. Some scholars argue the role and influencing factors of industry-university cooperation. Ankrah and Al-Tabbaa [7] have employed a systematic review of the literature on university-industry collaboration. They conclude that the cooperation between industry and universities can significantly improve the efficiency of innovation, especially under the pressures including rapid technological change, shorter product life cycles. Hemmert [17] finds that university researchers can enhance their acquisition of both the technological knowledge and scientific knowledge by a strong working relationship with industry partners. Santoro and Chakrabarti [18] have analyzed the firm size and technology centrality in industry-university interactions and they find large firms and small firms have different research relationships with university facilities. Using the data from 14 European countries, Rõigas et al. [19] find that the degree of internationalization is the main determinant of university-industry cooperation. Huggins and Prokop [20] explore the knowledge network structure of university-industry ties and they find that network structures between universities and other actors, principally firms, influence the patterns of regional innovation and development. Using a sample of 833 German manufacturing firms, Goel et al. [21] reveal that university scientists have somewhat higher difficulties initiating collaborations with large firms than that with small firms.

Other scholars have discussed the game model and contract of industry-university cooperation. There may be various contractual arrangements in the cooperation between industry and universities. As a key issue to promote the collaborative innovation of industry-university and to deal with the allocation of profits [22], many studies have discussed various contractual arrangements with industry-university cooperation for the joint development of new products in recent years. From the perspective of multi-stage alliance, $\mathrm{Xiao}$ and $\mathrm{Xu}$ [23] have analyzed the optimal contract arrangement of R\&D collaboration income under different environments. They suggest that managers may need to use a contingent contract accordingly to improve profits. Through a series of controlled behavioral experiments, Wuttke et al. [24] find that using a reward frame for sustaining supplier engagements significantly increases possibility for innovation project. Rahmani et al. [25] have studied the collaborative work dynamics in projects with co-production and point that effective contracts should be flexible in scope. Bhattacharya et al. [26] have analyzed the efficacy between milestone-based options contracts and buyout options contracts for coordinating R\&D partnerships. For the joint development of new products, Savva and Scholtes [27] formulate a two-stage model to compare three contracts between co-development, licensing and co-development with opt-out options. Further, Liu and Song [28] explore that how the producer inspires his cooperative research partner to reduce carbon emission.

The models that are discussed above do not consider the consumer learning and government subsidy for industry -university cooperation. Next, we review the literature on the consumer learning.

\subsection{Consumer Learning in Innovation Cooperation}

Recent research in innovation management has indicated that providing considerable attention to the consumer learning is essential. Co-creation with consumer is generally considered to seek to achieve or maintain strategic competitiveness by innovative firms [29]. Jeppesen and Molin [30] propose that 
'user-driven innovation' can be done by generating consumer innovation efforts and learning and innovation efforts from which a firm may well reside in the consumer environment. Roberts et al. [31] examine an approach to incentive the consumer's engagement in the innovation process and they explore consumers' perceptions of the innovation process. Sánchez-González and Herrera [32] have studied the effect of cooperation with customers on enterprises' innovation activities. They find that enterprises cooperating with customers will increase investments to a certain extent. By collecting 435 relevant papers on user innovation in firms, Cho and Lee [33] investigate the characteristics of the user innovation models including workshop-based, consortium-based, crowdsourcing-based and platform-based. They also reveal that there exist some research gaps.

Some scholars also have established game models based on consumer learning to study the cooperation between supply chains. Zhou et al. [34] have studies the impact of consumer learning on the enterprises' efforts and revenue sharing contracts in a supply chain. Papanastasiou and Savva [35] have established a simple two-period model to analyze dynamic pricing in the presence of consumer social learning. Gaur and Park [36] show that asymmetry in consumer learning has a significant effect on the optimal service levels of the retailers. Tsao and Sheen [37] study the problem of cost sharing mechanism and efforts between a manufacturer and two retailers considering the retailer's learning curve. They find that a certain proportion of cost sharing mechanism can improve the income of all participants.

In the literature, government subsidy and consumer learning are not incorporated into industry-university cooperation. Subsequently, we review the literature on government subsidy for innovation.

\subsection{Government Support for Innovation}

As the main way of ex ante incentive, government subsidy is considered as an effective policy tool to improve the R\&D investment of enterprises [38]. A large number of studies have confirmed the role of government subsidies in promoting enterprise $R \& D$ activities $[39,40]$. Government subsidies mean a lower cost of obtaining operating funds, which helps to alleviate the capital constraints faced by enterprises [41]. Government subsidies can also make up for the lack of return on investment brought by the externality and strengthen the R\&D motivation of enterprise [42]. Michalsen [43] studies the $R \& D$ policy of vertical related industry. It is concluded that when the concentration of downstream markets is high, the optimal R\&D policy is to provide subsidies for these enterprises. Otherwise, the optimal strategy is to provide tax incentives for downstream enterprises.

As Ankrah et al. point out, government plays a key role in facilitating the establishment and development of industry-university cooperation [44]. Against a background of rapid technological change, government support is considered as a tool of improving innovation efficiency between universities and industry [45]. Seppo et al. [46] investigate patterns and dynamics of governmental support measures comparing policies in 23 European countries and they reveal the amount of different support measures, are more co-financing from the private sector and depend less on the EU structural funds. Galan-Muros et al. highlight the importance of the combination of support at both strategic and operational levels for all university-business cooperation activities [47-53].

However, the above research does not pay attention to the issue of government subsidies in the multi-stage cooperation of industry-university and does not consider the effect of consumer learning on the government's subsidy to industry-university cooperation, either. In the current work, we study the multi-stage cooperation of industry-university with consumer learning and explore the optimal subsidy intensity under the above conditions [54-60].

\section{Models}

We focus on a cooperation system of green innovation with one enterprise, one research and development (R\&D) institute (this paper takes an example of a university) and one policy-maker (government). We assume that an enterprise and a university cooperate in the R\&D of green innovative 
products and the R\&D period is $\mathrm{M}$, so the behavior of consumers to purchase green innovative products is also divided into $M(M \geq 1)$ periods. For example, there are many generations of Apple phones and Apple Inc. has worked with some institutions and universities during every generation. Consumers cannot understand the true value of green innovative products and they update the expected value of green innovative products only through continuous learning (Zhou, Zhao, Xue and Gargeya [34]). In phrase $t$, we assume that the $R \& D$ costs of green innovation for the enterprise is $X_{t}$ and for the university is $Y_{t}$ in which the cost sharing proportion of the enterprise to the university is $\theta_{t}\left(0 \leq \theta_{t} \leq 1\right)$. So the proportion of the part of the university is $1-\theta_{t}$. Besides, we assume that the marginal profit that can be obtained from the sale of per unit green innovative product is $\rho_{m}$ in which the proportion of the part of the enterprise is $S$, so the proportion of the part of the university is $(1-S)$. In order to stimulate the research and development of green innovative products, the government can subsidize the investment for the enterprise and the university respectively, or subsidize green innovative products. Yet the general, we first take government subsidies for the university's R\&D costs into account and we assume that the proportion is $\delta$. We use $Q_{t}$ to represent the green innovative products' sales function which depends on the basic demand of the market and the investment in green innovation $R \& D$ by the enterprise and the university. In phrase $t(t \leq M)$, the green innovative products' sales function is given by

$$
Q_{t}=\alpha+\beta X_{t}^{A} Y_{t}^{B}+\widetilde{\varepsilon}
$$

Equation (1) is in Cobb-Douglas form [61-63]. We use $\alpha$ to denote the need of the green innovative products when the enterprise is independent of the university. In most practical situations, the higher the product value is, the more consumers are willing to buy the product (Zhou, Zhao, Xue and Gargeya [34]). Therefore, it reflects the basic demand of this kind of product the influence of basic performance (such as basic functions and qualities) of products on consumers' needs. $\beta$ is a positive constant and $\widetilde{\varepsilon}$ is a random variable with a mean of zero. A and B are the elasticity coefficients of $R \& D$ investment of the enterprise and the university respectively. When the sales volume of green innovative products increases, the returns of scale of $X$ and $Y$ decrease, that is, $A+B<1$. Equation (1) indicates that, the green innovation cooperation of the enterprise and the university has promoted the sales of products. The increase in sales depends on their respective green innovation R\&D investment, R\&D elasticity coefficient and interaction factors.

As the initial market demand is unknown, consumers can observe the quality and quantity information of products according to the previous stage of online sales and reviews [48,49]. We assume that $Q_{t}$ is observable while $\alpha$ is unobservable. Because $Q_{t}$ is a function that contains $\alpha$ and $Q_{t}$ can be used as a signal for $\alpha$. Potential consumers can guess $\alpha$ by observing $Q_{t}$ and get basic performance information and green innovation information of green products. In other words, when we use $D_{t}=\left\{Q_{1} \ldots Q_{t}\right\}$ to represent the sales volume of green innovative products in the previous $\mathrm{t}$ periods, through the observation of $D_{t}=\left\{Q_{1} \ldots Q_{t}\right\}$, we constantly update the expectations for $\alpha$. Let $D_{t-1}=\left\{Q_{1}, Q_{2}, \ldots, Q_{t-1}\right\}$ represent the history of the product sales in the previous $t-1$ periods. $E\left[\alpha \mid D_{t-1}\right]$ represents the consumer's expectation of $\alpha$ after observing $D_{t-1}$. When $t=1$, $E\left[\alpha \mid D_{0}\right]=\alpha_{0}$. When $t>1$, based on Equation (1),

$$
\alpha+\widetilde{\varepsilon}=Q_{t}-\beta X_{t}^{A} Y_{t}^{B}
$$

According to normal learning theory (Zhou, Zhao, Xue and Gargeya [34]), $E\left[\alpha \mid D_{t-1}\right]$ is given by

$$
E\left[\alpha \mid D_{t-1}\right]=\left(1-\tau_{t}\right) E\left[\alpha \mid D_{t-2}\right]+\tau_{t}\left(Q_{t-1}-\beta \bar{X}_{t-1}^{A} \bar{Y}_{t-1}^{B}\right)
$$

$\bar{X}_{t-1}^{A}$ and $\bar{Y}_{t-1}^{A}$ are the consumers' expectations of the enterprise and university's equilibrium investments in period $t-1$. Based on Equation (1), $\left(Q_{t-1}-b \bar{X}_{t-1}^{A} \bar{Y}_{t-1}^{A}\right)$ represents the basic demand for cooperative innovation products between enterprises and universities in every stage of cooperation. In other words, it is the market signal and $\tau_{t}$ is the learning factor. $E\left[\alpha \mid D_{t-2}\right]$ represents consumers' 
prior belief of the base demand. The Equation (2) shows that the updating of consumers' beliefs about basic demand for cooperative innovation products between enterprises and universities is the weighted average of previous belief and market signal.

According to the research of Zhou, Zhao, Xue and Gargeya [34], the learning factor $\tau_{t}$ is given by

$$
\tau_{t+1}=\frac{\tau_{t}}{1+\tau_{t}}
$$

The above formula shows that with the development of multi-stage game, consumer learning factors will gradually decrease and finally trend to zero. In the green innovation cooperation process of the multi-stage game between the enterprise and the university, the consumer's estimation of the basic demand information of the product market is more dependent on the estimated value that has been established in the past and the dependence on the earlier transmission of the signal is becoming weaker and weaker.

\section{Model Analysis}

This section may be divided by subheadings. It should provide a concise and precise description of the experimental results, their interpretation as well as the experimental conclusions that can be drawn.

\subsection{Green Innovation Investment and Subsidy Policy under Stackelberg Equilibrium}

When the enterprise is a leader and the university is a follower, the three-stage game among the government, the enterprise and the university will be carried out. In general, when the government issues an industrial policy, it will detail the subsidy measures and intensity for R\&D. In the first stage, the government first determines the subsidy ratio $\delta$ for the green innovation investment of the university. In the second stage, the enterprise announces its own green innovation R\&D investment $\left(X_{t}\right)$ and the proportion of cost sharing of the university's investment is $\theta_{t}$. In the third stage, according to the decisions of the government and the enterprise, the university decides its own level of R\&D investment in green innovation $\left(Y_{t}\right)$. So in phrase $t$, the objective function for the university can be represented by

$$
\pi_{r t}=\sum_{i=0}^{M-t} E\left[(1-S) \rho_{m} Q_{t+i}-\left(1-\theta_{t+i}-\delta\right) Y_{t+i} \mid D_{t+i-1}\right]
$$

The objective function for the enterprise can be represented by

$$
\pi_{m t}=\sum_{i=0}^{M-t} E\left[S \rho_{m} Q_{t+i}-X_{t+i}-\theta_{t+i} Y_{t+i} \mid D_{t+i-1}\right]
$$

The objective function for the government is the sum of profits between the enterprise and the university minus the amount of government subsidies which can be represented by

$$
\pi_{g}=\sum_{t=1}^{M} E\left[\rho_{m} Q_{t}-X_{t}-Y_{t}\right]
$$

By the backward induction, we can solve the Stackelberg equilibrium of green innovation cooperation among the government, the enterprise and the university under the condition of government subsidies. Using the first-order-condition of university's profit function, the optimal R\&D investment level of green innovation for the university in the third stage is given by

$$
\frac{\partial \pi_{r t}}{\partial Y_{t}}=\sum_{i=0}^{M-t}(1-S) \rho_{m} \frac{\partial E\left[Q_{t+i} \mid D_{t+i-1}\right]}{\partial Y_{t}}-\left(1-\theta_{t}-\delta\right)=0
$$


In order to figure out $Y_{t}$ in Equation (6), we need to get the expression of $\frac{\partial E\left[Q_{t+i} \mid D_{t+i-1}\right]}{\partial Y_{t}}$. According to Equation (1),

$$
\left\{\begin{array}{l}
E\left[Q_{t} \mid D_{t-1}\right]=E\left[\alpha \mid D_{t-1}\right]+\beta X_{t}{ }^{A} Y_{t}{ }^{B} \\
E\left[Q_{t+1} \mid D_{t}\right]=E\left[\alpha \mid D_{t}\right]+\beta X_{t+1}{ }^{A} Y_{t+1}{ }^{B} \\
E\left[Q_{t+2} \mid D_{t+1}\right]=E\left[\alpha \mid D_{t+1}\right]+\beta X_{t+2}{ }^{A} Y_{t+2}{ }^{B}
\end{array}\right.
$$

According to Equation (2),

$$
\left\{\begin{array}{l}
E\left[\alpha \mid D_{t-1}\right]=\left(1-\tau_{t}\right) E\left[\alpha \mid D_{t-2}\right]+\tau_{t}\left(Q_{t-1}-\beta \bar{X}_{t-1}{ }^{A} \bar{Y}_{t-1}{ }^{B}\right) \\
E\left[\alpha \mid D_{t}\right]=\left(1-\tau_{t+1}\right) E\left[\alpha \mid D_{t-1}\right]+\tau_{t+1}\left(Q_{t}-\beta \bar{X}_{t}^{A} \bar{Y}_{t}^{B}\right) \\
E\left[\alpha \mid D_{t+1}\right]=\left(1-\tau_{t+2}\right) E\left[\alpha \mid D_{t}\right]+\tau_{t+2}\left(Q_{t+1}-\beta \bar{X}_{t+1}{ }^{A} \bar{Y}_{t+1}{ }^{B}\right)
\end{array}\right.
$$

Based on Equations (7) and (8),

$$
\left\{\begin{aligned}
E\left[Q_{t} \mid D_{t-1}\right]= & E\left[\alpha \mid D_{t-1}\right]+\beta X_{t}^{A} Y_{t}^{B} \\
E\left[Q_{t+1} \mid D_{t}\right]= & \left(1-\tau_{t+1}\right) E\left[\alpha \mid D_{t-1}\right]+\tau_{t+1}\left(Q_{t}-\beta \bar{X}_{t}^{A} \bar{Y}_{t}^{B}\right)+\beta X_{t+1}{ }^{A} Y_{t+1}{ }^{B} \\
E\left[Q_{t+2} \mid D_{t+1}\right] & =\left(1-\tau_{t+2}\right)\left[\left(1-\tau_{t+1}\right) E\left[\alpha \mid D_{t-1}\right]+\tau_{t+1}\left(Q_{t}-\beta \bar{X}_{t}^{A} \bar{Y}_{t}^{B}\right)\right] \\
& +\tau_{t+2}\left(Q_{t+1}-\beta \bar{X}_{t+1}{ }^{A} \bar{Y}_{t+1}{ }^{B}\right)+\beta X_{t+2}{ }^{A} Y_{t+2}{ }^{B}
\end{aligned}\right.
$$

Therefore,

$$
\begin{array}{ll}
\frac{\partial E\left[Q_{t} \mid D_{t-1}\right]}{\partial X_{t}}=A \beta X_{t}^{A-1} Y_{t}^{B} & \frac{\partial E\left[Q_{t} \mid D_{t-1}\right]}{\partial Y_{t}}=B \beta X_{t}{ }^{A} Y_{t}^{B-1} \\
\frac{\partial E\left[Q_{t+i} \mid D_{t+i-1}\right]}{\partial X_{t}}=\tau_{t+i} A \beta X_{t}^{A-1} Y_{t}^{B} & \frac{\partial E\left[Q_{t+i} \mid D_{t+i-1}\right]}{\partial Y_{t}}=\tau_{t+i} B \beta X_{t}{ }^{A} Y_{t}^{B-1}
\end{array}
$$

Then substitute Equation (10) into Equation (6). $Y_{t}$ can be represented by

$$
Y_{t}=\left(\left(1-\theta_{t}-\delta\right) /\left((1-S) \rho_{m} B \beta\left(1+\sum_{i=1}^{M-t} \tau_{t+i}\right) X_{t}^{A}\right)\right)^{1 /(B-1)}
$$

In the second stage, the enterprise determines its $X$ and $\theta$ according to the university's $Y$. Substituting Equation (11) into Equation (4) and using the enterprise's profit function's first-order-condition, the optimal R\&D investment level of green innovation of the enterprise and the proportion of cost sharing of university's investment are given by

$$
\begin{gathered}
\frac{\partial \pi_{m t}}{\partial X_{t}}=\sum_{i=0}^{M-t} S \rho_{m}\left(\frac{\partial E\left[Q_{t+i} \mid D_{t+i-1}\right]}{\partial X_{t}}+\frac{\partial E\left[Q_{t+i} \mid D_{t+i-1}\right]}{\partial Y_{t}} \cdot \frac{\partial Y_{t}}{\partial X_{t}}\right)-1-\theta_{t} \cdot \frac{\partial Y_{t}}{\partial X_{t}}=0 \\
\frac{\partial \pi_{m t}}{\partial \theta_{t}}=\sum_{i=0}^{M-t}\left[S \rho_{m} \frac{\partial E\left[Q_{t+i} \mid D_{t+i-1}\right]}{\partial \theta_{t}}\right]-Y_{t}-\theta_{t} \cdot \frac{\partial Y_{t}}{\partial \theta_{t}}=0
\end{gathered}
$$

Based on Equations (12) and (13), the Stackelberg equilibrium solution of green innovation cooperation under consumer learning can be represented by

$$
\begin{gathered}
\theta_{t}^{1}=\left\{\begin{array}{cc}
1-\delta-(1-\delta)(1-S) /(B+S-B S) & B+2 S-B S>1 \\
0 & \text { else }
\end{array}\right. \\
X_{t}^{1}=\left[\left(A^{1-B} B^{B} \rho_{m} \beta\left(1+\sum_{i=1}^{M-t} \tau_{t+i}\right)(B+S-B S)(1-\delta)^{-B}\right)\right]^{1 /(1-A-B)} \\
Y_{t}^{1}=\left[\left(A^{A} B^{1-A} \rho_{m} \beta\left(1+\sum_{i=1}^{M-t} \tau_{t+i}\right)(B+S-B S)(1-\delta)^{A-1}\right)\right]
\end{gathered}
$$


According to Equation (14), when $B+2 S-B S>1$, the enterprise shares the university's investment of green innovation under consumer learning. When $\partial \theta_{t}^{1} / \partial \delta=(1-S) /(B+S-B S)-$ $1<0$, it shows that when the enterprise shares the university's investment, the proportion $\theta$ decreases with the increase of the subsidy ratio from the government to the university. According to Equations (15) and (16), when $\partial X_{t}^{1} / \partial \delta>0$ and $\partial Y_{t}^{1} / \partial \delta>0$, it shows that the enterprise and the university's green $R \& D$ investment increases with the increase of the government subsidy ratio of green innovation.

In the first stage, according to $X, Y$ and $\theta$, the government determines its subsidy ratio to the university. Using the first-order-condition of government's utility function, the optimal subsidy ratio to the university can be represented by

$$
\frac{\partial \pi_{g}}{\partial \delta}=\sum_{t=1}^{M}\left[\rho_{m}\left(\frac{\partial Q_{t}}{\partial X_{t}^{1}} \cdot \frac{\partial X_{t}^{1}}{\partial \delta}+\frac{\partial Q_{t}}{\partial Y_{t}^{1}} \cdot \frac{\partial Y_{t}^{1}}{\partial \delta}\right)-\frac{\partial X_{t}^{1}}{\partial \delta}-\frac{\partial Y_{t}^{1}}{\partial \delta}\right]=0
$$

Based on Equations (10), (15) and (16), the optimal subsidy ratio $\delta^{M S}$ can be given by

$$
\delta^{M S}=\left\{\begin{array}{cc}
\frac{1-(B+S-B S)\left(1+\sum_{i=1}^{M-t} \tau_{t+i}\right)}{1-A(B+S-B S)\left(1+\sum_{i=1}^{M-t} \tau_{t+i}\right)} & 1-(B+S-B S)\left(1+\sum_{i=1}^{M-t} \tau_{t+i}\right)>0 \\
0 & \text { else }
\end{array}\right.
$$

Then we substitute Equation (18) into Equations (14)-(16). In multi-stage Stackelberg equilibrium, the optimal proportions that the enterprise's investment accounts for the university's investment $\left(\delta_{t}^{M S}\right)$, the optimal R\&D investment level of green innovation of the enterprise $\left(X_{t}^{M S}\right)$ and the optimal $R \& D$ investment level of green innovation of the university $\left(Y_{t}^{M S}\right)$ are given respectively by

$$
\begin{gathered}
\theta_{t}^{M S}=\left\{\begin{array}{cc}
\frac{(1-A)(B+S-B S)\left(1+\sum_{i=1}^{M-t} \tau_{t+i}\right)}{1-A(B+S-B S)\left(1+\sum_{i=1}^{M-t} \tau_{t+i}\right)}\left(1-\frac{1-S}{B+S-B S}\right) & B+2 S-B S>1 \\
0 & \text { else }
\end{array}\right. \\
X_{t}^{M S}=\left[A^{1-B} B^{B} \rho_{m} \beta\left(1+\sum_{i=1}^{M-t} \tau_{t+i}\right)(B+S-B S)\left(\frac{(1-A)(B+S-B S)\left(1+\sum_{i=1}^{M-t} \tau_{t+i}\right)}{1-A(B+S-B S)\left(1+\sum_{i=1}^{M-t} \tau_{t+i}\right)}\right)\right] \\
Y_{t}^{M S}=\left[A^{A} B^{1-A} \rho_{m} \beta\left(1+\sum_{i=1}^{M-t} \tau_{t+i}\right)(B+S-B S)\left(\frac{(1-A)(B+S-B S)\left(1+\sum_{i=1}^{M-t} \tau_{t+i}\right)}{1-A(B+S-B S)\left(1+\sum_{i=1}^{M-t} \tau_{t+i}\right)}\right]\right.
\end{gathered}
$$

Due to $\tau_{t+1}=\tau_{t} /\left(1+\tau_{t}\right)$, we obtain $1+\sum_{i=1}^{M-t} \tau_{t+i}=1+\sum_{i=1}^{M-t} \tau_{2} /\left(1+(t+i-2) \tau_{2}\right)$. Therefore, through partial derivation for initial learning factors $\tau_{2}, \partial\left(1+\sum_{i=1}^{M-t} \tau_{t+i}\right) / \partial \tau_{2}=$ $\sum_{i=1}^{M-t} 1 /\left(1+(t+i-2) \tau_{2}\right)^{2}>0$. In phrase $t, \partial\left(1+\sum_{i=1}^{M-t} \tau_{t+i}\right) / \partial t=\sum_{i=1}^{M-t}-\tau_{2}^{2} /\left(1+(t+i-2) \tau_{2}\right)^{2}<0$. Based on Equations (18) and (19), $\partial \delta^{M S} / \partial\left(1+\sum_{i=1}^{M-t} \tau_{t+i}\right)<0, \partial \theta_{t}^{M S} / \partial\left(1+\sum_{i=1}^{M-t} \tau_{t+i}\right)>0$, so $\partial \delta^{M S} / \partial \tau_{2}<0, \partial \delta^{M S} / \partial t>0, \partial \theta_{t}^{M S} / \partial \tau_{2}>0, \partial \theta_{t}^{M S} / \partial t<0$. Based on Equation (19), $\partial \theta_{t}^{M S} / \partial S>0$. Then, we propose Proposition 1.

Proposition 1. With the consumer learning, in the three stage Stackelberg game model of the government, the enterprises and the university, 
(1) The optimal subsidy ratio of government to the university's green RED investment decreases with the increase of initial learning factors but increases with the increase of cooperation cycle.

(2) The optimal level of green innovation RED investment increases with the increase of initial consumer learning factors but decreases with the increase of cooperation cycle.

(3) The optimal green RED investment of the enterprise and the university increase with the increase of subsidy ratio of the government.

(4) The optimal cost sharing proportion of the enterprise to the university's investment increases with the increase of profit distribution ratio.

The Proposition 1 shows that the green innovation subsidy of the government can not only increase the university's R\&D investment but also improve the enterprise's R\&D investment. The initial consumer learning factors and the cooperative innovation cycle of the enterprise and the university have different influences on the government's optimal subsidy ratio and the enterprise's optimal cost sharing. The government pays more attention to long-term social welfare goals while the enterprise pays more attention to short-term profit targets. Therefore, the longer the green innovation cooperation cycle is, the higher the government's subsidy to the university is and the lower the enterprise's optimal proposition is. Most of the products with higher initial learning factors for consumers are fast moving consumer goods (such as mobile phones) and most of the lower initial learning factors are basic products (such as medicine). The government has a higher subsidy for the products with lower initial learning factors and the enterprise has a higher proposition for the products with higher initial learning factors.

\subsection{Green Innovation Investment and Subsidy Policy under the Full Cooperation of the Enterprise and the University}

Under complete information, the enterprise and the university can cooperate fully. They pursue the maximization of total profit according to the government's green innovation subsidy policy. In the first stage, the government decides the subsidy ratio to the university. In the second stage, the enterprise and the university maximize the total profit according to the green innovation subsidy ratio of the government. So, the objective function of the enterprise and the university can be represented by

$$
\max \pi=\max \sum_{i=0}^{M-t} E\left[\rho_{m} Q_{t+i}-X_{t+i}-(1-\delta) Y_{t+i} \mid D_{t+i-1}\right]
$$

The first-order derivative of $X_{t}$ and $Y_{t}$ respectively are

$$
\begin{gathered}
\frac{\partial \pi}{\partial Y_{t}}=\sum_{i=0}^{M-t}\left[\rho_{m} \frac{\partial E\left[Q_{t+i} \mid D_{t+i-1}\right]}{\partial Y_{t}}\right]-(1-\delta)=0 \\
\frac{\partial \pi}{\partial X_{t}}=\sum_{i=0}^{M-t}\left[\rho_{m} \frac{\partial E\left[Q_{t+i} \mid D_{t+i-1}\right]}{\partial X_{t}}\right]-1=0
\end{gathered}
$$

Then we obtain the optimal green $R \& D$ investment when the enterprise and the university cooperate fully which is as follows.

$$
\begin{gathered}
X_{t}^{2}=\left[A^{1-B} B^{B} \rho_{m} \beta\left(1+\sum_{i=1}^{M-t} \tau_{t+i}\right)(1-\delta)^{-B}\right]^{1 /(1-A-B)} \\
Y_{t}^{2}=\left[A^{A} B^{1-A} \rho_{m} \beta\left(1+\sum_{i=1}^{M-t} \tau_{t+i}\right)(1-\delta)^{A-1}\right]^{1 /(1-A-B)}
\end{gathered}
$$


Based on Equations (25) and (26), $\partial X_{t}^{2} / \partial \delta>0, \partial Y_{t}^{2} / \partial \delta>0$. It shows that the two-optimal green innovation R\&D investments increase with the increase of government subsidy to R\&D investment.

In the first stage, the government decides its subsidy ratio according to the green $R \& D$ investment of the enterprise and the university. According to Equation (5), the optimal subsidy ratio is given by

$$
\frac{\partial \pi_{g}}{\partial \delta}=\sum_{t=1}^{M}\left[\rho_{m}\left(\frac{\partial Q_{t}}{\partial X_{t}^{2}} \cdot \frac{\partial X_{t}^{2}}{\partial \delta}+\frac{\partial Q_{t}}{\partial Y_{t}^{2}} \cdot \frac{\partial Y_{t}^{2}}{\partial \delta}\right)-\frac{\partial X_{t}^{2}}{\partial \delta}-\frac{\partial Y_{t}^{2}}{\partial \delta}\right]=0
$$

Then based on Equations (10), (25) and (26), the optimal subsidy ratio $\delta^{M C}$ can be represented by

$$
\delta^{M C}= \begin{cases}\sum_{i=1}^{M-t} \tau_{t+i} /\left(A\left(1+\sum_{i=1}^{M-t} \tau_{t+i}\right)-1\right) & A\left(1+\sum_{i=1}^{M-t} \tau_{t+i}\right)-1>0 \\ 0 & \text { else }\end{cases}
$$

Substituting Equation (28) into Equations (25) and (26), under multi-stage green innovation cooperation, the optimal R\&D investment of the enterprise $X_{t}^{M C}$ and the optimal R\&D investment of the university $Y_{t}^{M C}$ are given respectively by

$$
\begin{aligned}
X_{t}^{M C} & =\left[A^{1-B}(1-A)^{-B} B^{B} \rho_{m} \beta\left(1+\sum_{i=1}^{M-t} \tau_{t+i}\right)^{1-B}\left(1-A\left(1+\sum_{i=1}^{M-t} \tau_{t+i}\right)\right)^{B}\right]^{1 /(1-A-B)} \\
Y_{t}^{M C} & =\left[A^{A}(1-A)^{A-1} B^{1-A} \rho_{m} \beta\left(1+\sum_{i=1}^{M-t} \tau_{t+i}\right)^{A}\left(1-A\left(1+\sum_{i=1}^{M-t} \tau_{t+i}\right)\right)^{1-A}\right]^{1 /(1-A-B)}
\end{aligned}
$$

From Equation (28), $\partial \delta^{M C} / \partial\left(\sum_{i=1}^{M-t} \tau_{t+i}\right)=-(1-A) /\left(A\left(1+\sum_{i=1}^{M-t} \tau_{t+i}\right)-1\right)^{2}<0$ and $\partial(1+$ $\left.\sum_{i=1}^{M-t} \tau_{t+i}\right) / \partial \tau_{2}>0, \partial\left(1+\sum_{i=1}^{M-t} \tau_{t+i}\right) / \partial t<0$, so $\partial \delta^{M C} / \partial \tau_{2}<0, \partial \delta^{M C} / \partial t>0$. We can get that the subsidy ratio of the government to the green innovation $R \& D$ investment decreases with the increase of the initial consumer learning factors but increases with the increase of the cooperative cycle. Therefore, we propose Proposition 2.

Proposition 2. With the consumer learning, when the enterprise and the university cooperate fully,

(1) The government's optimal subsidy for green innovation RED investment decreases with the increase of initial consumer learning factors but increases with the increase of green innovation cooperative RED cycle.

(2) The optimal green RED investment of the enterprise and the university increase with the increase of government subsidies to the university.

The Proposition 2 shows that when the enterprise cooperates with the university fully, the government's one-side subsidy to the university can enhance both the enterprise's and the university's R\&D investment.

\section{Static Comparative Analysis}

\subsection{Comparison of Optimal Subsidy between Stackelberg and Full Cooperation}

When the enterprise is the leader and the university is the follower, according to Equation (18), the condition for the government to subsidize the university is $1-(B+S-B S)\left(1+\sum_{i=1}^{M-t} \tau_{t+i}\right)>0$. $1+\sum_{i=1}^{M-t} \tau_{t+i}$ is a decreasing function with a cooperation cycle of $t$ and this condition is easier to achieve 
in the later stage of green R\&D cooperation or when initial consumer learning factors are low. When the enterprise cooperates with the university fully, the condition for the government subsidies to the university is $A\left(1+\sum_{i=1}^{M-t} \tau_{t+i}\right)-1>0$. This condition is easier to achieve in the earlier stage of green R\&D cooperation or when initial consumer learning factors are relatively high. In the above two situations, the optimal green R\&D investment of the enterprise and the university increases with the increase of government subsidies to R\&D investment. In order to make the government subsidies more efficient, when the enterprise is the leader and the university is the follower, the government should subsidize the green innovation of the university in the later stage; when the enterprise cooperates with the university fully, the government should subsidize the green innovation of the university in time. When initial consumer learning factors are low (these products are often basic products and initial consumer learning factors are lower, so the long-term learning is needed, such as the curative effect of some medicine), the government should subsidize the green innovation of the university in time. When consumer initial learning factors are high (these products are often fast-moving consumer goods and consumer initial learning factors are higher, so the performance of products can be mastered in a short time, such as the efficacy of mobile phones), the government should appropriately lag the subsidies for the university. The specific subsidies and subsidy ratio depend on the comprehensive role of learning factors and green innovation cooperation cycle.

\subsection{Comparison of Optimal Subsidy between Multi-Stage and Single Stage Cooperation}

When the enterprise is the leader and the university is the follower, without considering consumer learning factors, similar to the analysis of 4.1 , the government's optimal subsidy ratio $\delta^{S S}$ is given by

$$
\delta^{S S}=(1-(B+S-B S)) /(1-A(B+S-B S)) \quad B+S-B S<1
$$

Comparing Equation (18) with Equation (31), we obtain $\delta^{M S}<\delta^{S S}$. It shows that when the government subsidizes the university, the government's optimal subsidy ratio is less than that of single stage cooperation under consumer learning.

When the enterprise and the university are in Stackelberg game in single stage cooperation, without considering consumer learning factors, similar to the analysis of 4.1, the optimal proportion of the enterprise's cost sharing to the university's R\&D investment $\theta_{t}^{S S}$ is given by

$$
\theta_{t}^{S S}=\left\{\begin{array}{lc}
\frac{(1-A)(B+S-B S)}{1-A(B+S-B S)}\left(1-\frac{1-S}{B+S-B S}\right) & B+2 S-B S>1 \\
0 & \text { else }
\end{array}\right.
$$

Comparing Equation (19) with Equation (32), we obtain $\theta_{t}^{M S}>\theta_{t}^{S S}$. It shows that when the enterprise partially undertakes the university's $R \& D$ investment, the optimal proportion of the enterprise is greater than that of single stage under consumer learning.

When the enterprise cooperates with the university fully, without considering consumer learning factors, similar to the analysis of 4.2 , the government's optimal subsidy ratio is $0\left(\delta^{S C}=0\right)$. It shows that when the enterprise cooperates with the university fully in single stage, the government does not subsidize the university and the enterprise and the university will achieve the profit maximization under the market mechanism. Compared with Equation (28), we obtain $\delta^{M C}>\delta^{S C}$. It shows that the optimal subsidy ratio of the multi stage is greater than that of the single stage with consumer learning. Then, we propose Proposition 3.

\section{Proposition 3.}

(1) The optimal subsidy ratio of the multi stage is less than that of the single stage under the Stackelberg equilibrium. 
(2) The optimal cost sharing proportion of the multi stage is greater than that of the single stage under Stackelberg equilibrium.

(3) The optimal subsidy ratio of the multi stage is greater than that of the single stage under the equilibrium of green innovation cooperation.

The Proposition 3 shows that the optimal subsidy of the government to the multi-stage green innovation cooperation is quite different from that of the single stage. Compared with the single stage, the government pays more attention to long-term social welfare in the multi stage, so when the enterprise and the university cooperate for a long time, the optimal subsidy ratio will be increased and when the enterprise cooperates with the university inadequately, the optimal subsidy ratio will be decreased. In the multi-stage of $R \& D$ cooperation, the enterprise is the leader under Stackelberg game but it still pays attention to long-term profit and improves investment into the university.

\section{Numerical Simulation}

Through the above analysis, we can conclude that consumer learning factors and the green innovation cooperation cycle will affect the optimal R\&D investment of the enterprise and the university and the optimal government subsidies. The analytical functions of the optimal R\&D investment and the optimal government subsidies are more complex. Therefore, we assign some parameters of the above formulas and discuss the conclusions of this paper through numerical simulation. Considering that the main contribution of this paper is to introduce consumer learning into the three-stage game of the government, the enterprise and the university, we take consumer initial learning factors and the green innovation cooperation cycle as an example to evaluate the optimal subsidy ratio and the optimal R\&D investment of the enterprise and the university. The numerical simulation is mainly for Stackelberg equilibrium and the numerical analysis software is Matlab.

\subsection{The Influence of Consumer Learning on the Optimal Government's Subsidy Ratio}

In this case, we let $A=0.3, B=0.1, S=0.6,0.8, M=20$ and the initial learning factor $\tau_{2}$ adds from 0.2 to 0.5 . Through numerical analysis, we consider the influence of consumer learning factors and green innovation cooperation cycle on the optimal government subsidies. The results are shown in Figure 1.

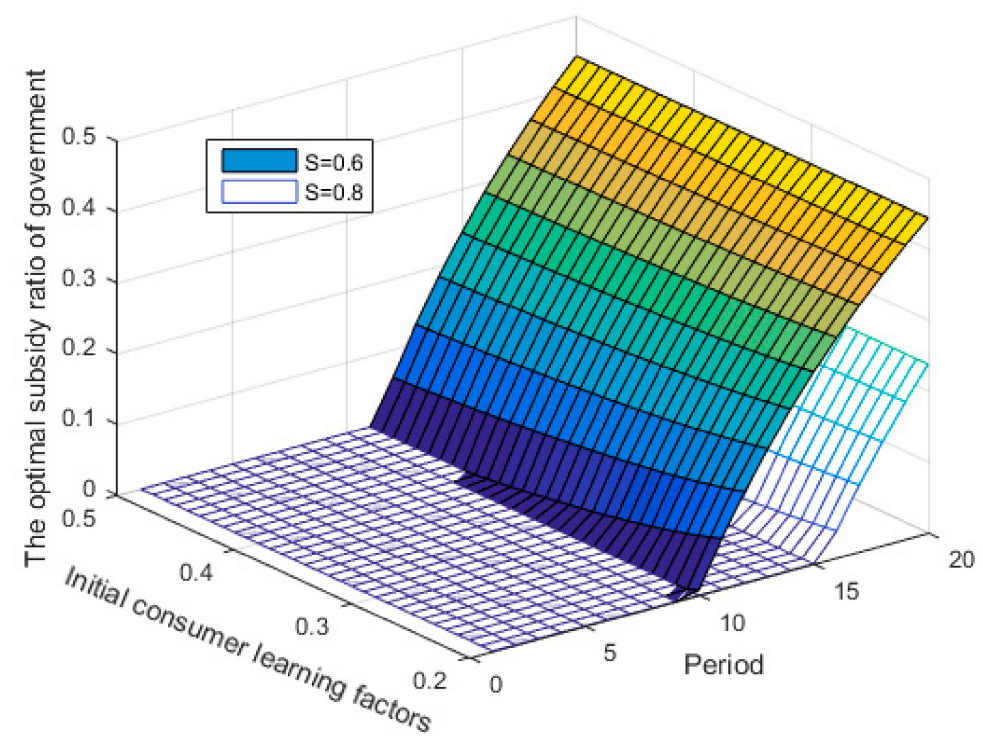

Figure 1. The influence of consumer learning factors and green innovation cooperation cycle on the optimal government subsidies. 
As Figure 1 shows, the optimal subsidy ratio of the government to the university decreases with the increase of initial learning factors but increases with the increase of green innovation cooperation cycle. At the last stage, consumers are no longer learning. At this point, the optimal subsidy ratio at any learning level equals the optimal subsidy ratio with no consumer learning. When initial consumer learning factors are low, the government should subsidize the green innovation of the university in time. When initial consumer learning factors are high, the government should appropriately lag the subsidies for the university. The specific subsidies and subsidy ratio depend on the comprehensive role of learning factors and green innovation cooperation cycle.

\subsection{The Influence of Consumer Learning on the Optimal RED Investment}

In this case, we let $A=0.3, B=0.1, S=0.6,0.8, \mathrm{M}=20, \rho_{m}=100, \beta=0.8$ and the initial learning factor $\tau_{2}$ adds from 0.2 to 0.5 . The influence of initial consumer learning factors and green innovation cooperation cycle on the optimal $R \& D$ investment of the enterprise and the university is shown in Figures 2 and 3 respectively.

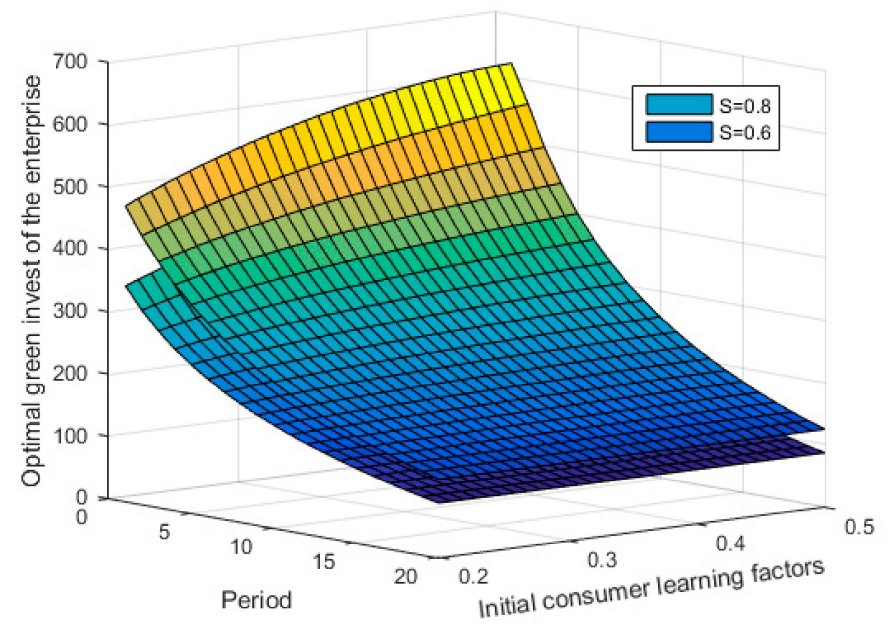

Figure 2. The influence of consumer initial learning factors and green innovation cooperation cycle on the optimal research and development (R\&D) investment for the enterprise.

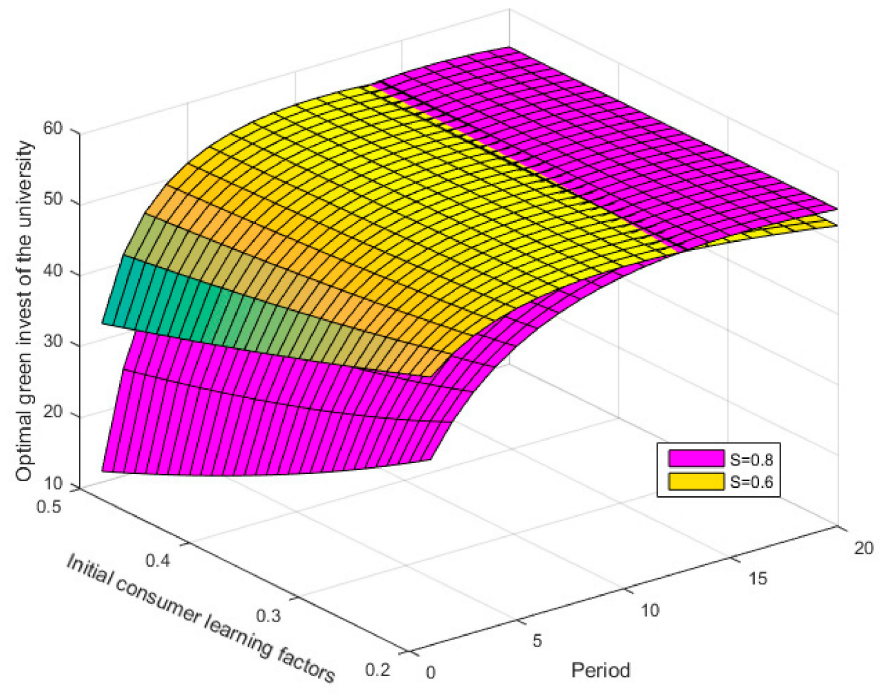

Figure 3. The influence of consumer initial learning factors and green innovation cooperation cycle on the optimal R\&D investment for the university. 
As Figure 2 shows, the optimal R\&D investment of the enterprise increases with the increase of initial learning factors but decreases with the increase of green innovation cooperation cycle. At the last stage, consumers are no longer learning. At this point, the optimal R\&D investment of the enterprise at any learning level equals the optimal R\&D investment of the enterprise under no consumer learning.

As Figure 3 shows, the optimal green R\&D investment of the university decreases with the increase of initial learning factors and increases with the increase of green innovation cooperation cycle.

\section{Conclusions}

This paper studies the optimal green investment strategies of cooperation innovation between industry and university with consumer learning and government subsidy. We analyze a cooperation system of one enterprise, one university and one policy-maker (government) under the multi-stage scenario due to consumer learning. The enterprise and the university cooperate to develop a certain green product. They invest the R\&D respectively and the enterprise share a part R\&D cost of the university. The government subsidizes green R\&D innovation of the university. We further develop a game model to analyze the optimal strategies of the enterprise, the university and the policy-maker with consumer learning and government subsidy. Then we compare the difference of optimal subsidy between the single-stage green innovation cooperation and the multi-stage green innovation cooperation. The research shows that consumers' initial learning factors and green innovation cooperation cycle have a significant impact on the optimal input level of the enterprise and the university and also have a significant impact on the optimal subsidy of the government. The optimal subsidy ratio of the government to university decreases with the increase of the initial consumer learning factor but increases with the increase of the green innovation cooperation cycle, under the two equilibria in which the enterprise is a leader and they cooperate fully. The optimal level of the enterprise's cost sharing increases with the increase of the initial consumer learning factor but decreases with the increase of the green innovation cooperation cycle under Stackelberg equilibrium. While the optimal proportion of the government subsidy in multi-stage green innovation cooperation is less than that in the single stage and optimal level of the enterprise's cost sharing in multi-stage green innovation cooperation is greater than that in the single stage under full cooperation equilibrium. The specific government subsidy and subsidy ratio depend on the comprehensive role of consumer learning factors and green innovation cooperation cycle. In the end, we propose that the government should subsidize the university in time when the initial consumer learning factor is low; the government subsidy should be properly lagged when the initial consumer learning factor of is high.

Our paper contributes theoretically in several ways. Firstly, considering consumer learning, we have developed a framework for industry-university cooperation from single stage to multi stage. Secondly, we introduce and study the role of the government subsidy in improving the green innovation cooperation between the enterprise and the university. Thirdly, we argue the optimal level of government subsidy according to the initial consumer learning factor. Especially, when the consumer's learning factor is different, the optimal subsidy moment should be also different

There also exist some limitations in this study. First, we assume that the government only provides subsidies to the university. But, in reality, the government maybe subsidizes both the university and the enterprise. Therefore, future study can be extended by considering that both the university and the enterprise are subsidized by the government. Second, we assume that the university's investment of innovation is subsidized by the government. In reality, there is the case that the government subsidizes the quantity of green production. The optimal strategies of the enterprise, university and government should also be investigated by considering the subsidy based on the quantity of green production. Further, we will conduct empirical research to make our research more scientific and practical.

Author Contributions: W.W. and S.-B.T. conceived, designed the study. W.W., K.Y. and C.-C.C. contributed significantly to the analysis and manuscript preparation. W.W., K.Y. and S.M. performed the model analyses and wrote the manuscript. W.W., S.L., C.M. and C.-C.C. revised the paper. 
Acknowledgments: This paper is supported by the National Social Science Foundation of China (No. 17BGL025), Tianjin Science and Technology Development Strategy Research Project (No. 17ZLZXZF00330); Education reform and practical project of Guangdong province (No. 38030105); National Natural Science Foundation of China (Grant No. 71473066) and Zhongshan City Science and Technology Bureau Project (No. 2017B1015).

Conflicts of Interest: The authors declare no conflict of interest.

\section{References}

1. Iyer, G.; Soberman, D.A. Social responsibility and product innovation. Mark. Sci. 2016, 35, 727-742. [CrossRef]

2. Sexton, S.E.; Sexton, A.L. Conspicuous conservation: The prius halo and willingness to pay for environmental bona fides. J. Environ. Econ. Manag. 2014, 67, 303-317. [CrossRef]

3. Luo, X.; Du, S. Good companies launch more new products. Harv. Bus. Rev. 2012, 90, 28.

4. Zhao, Y.; Yang, S.; Narayan, V.; Zhao, Y. Modeling consumer learning from online product reviews. Mark. Sci. 2012, 32, 153-169. [CrossRef]

5. Roberts, J.H.; Urban, G.L. Modeling multiattribute utility, risk, and belief dynamics for new consumer durable brand choice. Manag. Sci. 1988, 34, 167-185. [CrossRef]

6. Senecal, S.; Nantel, J. The influence of online product recommendations on consumers' online choices. J. Retail. 2004, 80, 159-169. [CrossRef]

7. Ankrah, S.; Al-Tabbaa, O. Universities-industry collaboration: A systematic review. Scand. J. Manag. 2015, 31, 387-408. [CrossRef]

8. Lehrer, M.; Nell, P.; Gärber, L. A national systems view of university entrepreneurialism: Inferences from comparison of the german and us experience. Res. Policy 2009, 38, 268-280. [CrossRef]

9. Woolgar, L. New institutional policies for university-ndustry links in japan. Res. Policy 2007, 36, 1261-1274. [CrossRef]

10. Gertner, D.; Roberts, J.; Charles, D. University-industry collaboration: A cops approach to ktps. J. Knowl. Manag. 2011, 15, 625-647. [CrossRef]

11. Hinloopen, J. Subsidizing R\&D cooperatives. De Econ. 2001, 149, 313-345. [CrossRef]

12. Yalabik, B.; Fairchild, R.J. Customer, regulatory, and competitive pressure as drivers of environmental innovation. Int. J. Prod. Econ. 2011, 131, 519-527. [CrossRef]

13. Choudhary, A.; Suman, R.; Dixit, V.; Tiwari, M.K.; Fernandes, K.J.; Chang, P.C. An optimization model for a monopolistic firm serving an environmentally conscious market: Use of chemical reaction optimization algorithm. Int. J. Prod. Econ. 2015, 164, 409-420. [CrossRef]

14. Jiang, W.; Chen, X. Optimal strategies for manufacturer with strategic customer behavior under carbon emissions-sensitive random demand. Ind. Manag. Data Syst. 2016, 116, 759-776. [CrossRef]

15. Bercovitz, J.E.L.; Feldman, M.P. Fishing upstream: Firm innovation strategy and university research alliances. Res. Policy 2007, 36, 930-948. [CrossRef]

16. Perkmann, M.; Neely, A.; Walsh, K. How should firms evaluate success in university-industry alliances? A performance measurement system. R D Manag. 2011, 41, 202-216. [CrossRef]

17. Hemmert, M. Knowledge acquisition by university researchers through company collaborations: Evidence from South Korea. Sci. Public Policy 2016, 44, 199-210. [CrossRef]

18. Santoro, M.D.; Chakrabarti, A.K. Firm size and technology centrality in industry-university interactions. Res. Policy 2002, 31, 1163-1180. [CrossRef]

19. Rõigas, K.; Seppo, M.; Varblane, U.; Mohnen, P. Which firms use universities as cooperation partners?-The comparative view in Europe. Int. J. Technol. Manag. 2018, 76. [CrossRef]

20. Huggins, R.; Prokop, D. Network structure and regional innovation: A study of university-industry ties. Urban Stud. 2016, 54, 931-952. [CrossRef]

21. Goel, R.K.; Göktepe-Hultén, D.; Grimpe, C. Who instigates university-industry collaborations? University scientists versus firm employees. Small Bus. Econ. 2017, 48, 503-524. [CrossRef]

22. Mihm, J. Incentives in new product development projects and the role of target costing. Manag. Sci. 2010, 56, 1324-1344. [CrossRef]

23. Xiao, $\mathrm{W} . ; \mathrm{Xu}, \mathrm{Y}$. The impact of royalty contract revision in a multistage strategic R\&D alliance. Manag. Sci. 2012, 58, 2251-2271. [CrossRef] 
24. Wuttke, D.A.; Donohue, K.; Siemsen, E. Initiating supplier new product development projects: A behavioral investigation. Prod. Oper. Manag. 2018, 27, 80-99. [CrossRef]

25. Rahmani, M.; Roels, G.; Karmarkar, U.S. Collaborative work dynamics in projects with co-production. Prod. Oper. Manag. 2016, 26, 686-703. [CrossRef]

26. Bhattacharya, S.; Gaba, V.; Hasija, S. A comparison of milestone-based and buyout options contracts for coordinating R\&D partnerships. Manag. Sci. 2016, 61, 963-978. [CrossRef]

27. Savva, N.; Scholtes, S. Opt-out options in new product co-development partnerships. Prod. Oper. Manag. 2015, 23, 1370-1386. [CrossRef]

28. Liu, K.; Song, H. Contract and incentive mechanism in low-carbon R\&D cooperation. Supply Chain Manag. 2017, 22, 270-283. [CrossRef]

29. Wong, T.Y.T.; Peko, G.; Sundaram, D.; Piramuthu, S. Mobile environments and innovation co-creation processes \& ecosystems. Inf. Manag. 2016, 53, 336-344. [CrossRef]

30. Jeppesen, L.B.; Molin, M.J. Consumers as co-developers: Learning and innovation outside the firm. Technol. Anal. Strateg. Manag. 2003, 15, 363-383. [CrossRef]

31. Roberts, D.; Baker, S.; Walker, D. Can we learn together? Co-creating with consumers. Int. J. Mark. Res. 2005, 47, 407-427. [CrossRef]

32. Sánchez-González, G.; Herrera, L. Effects of customer cooperation on knowledge generation activities and innovation results of firms. Bus. Res. Q. 2014, 17, 292-302. [CrossRef]

33. Cho, C.; Lee, S. How firms can get ideas from users for sustainable business innovation. Sustainability 2015, 7, 16039-16059. [CrossRef]

34. Zhou, J.; Zhao, X.; Xue, L.; Gargeya, V. Double moral hazard in a supply chain with consumer learning. Decis. Support Syst. 2012, 54, 482-495. [CrossRef]

35. Papanastasiou, Y.; Savva, N. Dynamic pricing in the presence of social learning and strategic consumers. Manag. Sci. 2015. [CrossRef]

36. Gaur, V.; Park, Y.H. Asymmetric consumer learning and inventory competition. Manag. Sci. 2007, 53, $227-240$. [CrossRef]

37. Tsao, Y.C.; Sheen, G.J. Effects of promotion cost sharing policy with the sales learning curve on supply chain coordination. Comput. Oper. Res. 2012, 39, 1872-1878. [CrossRef]

38. Carboni, O.A. R\&D subsidies and private R\&D expenditures: Evidence from italian manufacturing data. Int. Rev. Appl. Econ. 2011, 25, 419-439. [CrossRef]

39. David, P.A.; Hall, B.H.; Toole, A.A. Is public R\&D a complement or substitute for private R\&D? A review of the econometric evidence. Res. Policy 2000, 29, 497-529. [CrossRef]

40. Matthias, A.; Dirk, C. The effects of public R\&D subsidies on firms' innovation activities: The case of eastern germany. J. Bus. Econ. Stat. 2004, 21, 226-236.

41. Chen, V.Z.; Li, J.; Shapiro, D.M.; Zhang, X. Ownership structure and innovation: An emerging market perspective. Asia Pac. J. Manag. 2012, 31, 1-24. [CrossRef]

42. Jaumandreu, J. Barriers to innovation and subsidy effectiveness. Rand J. Econ. 2005, 36, 930-950.

43. Michalsen, A. R\&D policy in a vertically related industry. Econ. Innov. New Technol. 2012, 21, 737-751. [CrossRef]

44. Perkmann, M.; King, Z.; Pavelin, S. Engaging excellence? Effects of faculty quality on university engagement with industry. Res. Policy 2011, 40, 539-552. [CrossRef]

45. Barnes, T.; Pashby, I.; Gibbons, A. Effective university-industry interaction: A multi-case evaluation of collaborative R\&D projects. Eur. Manag. J. 2002, 20, 272-285. [CrossRef]

46. Seppo, M.; Rõigas, K.; Varblane, U. Governmental support measures for university-industry cooperation-Comparative view in Europe. J. Knowl. Econ. 2014, 5, 388-408. [CrossRef]

47. Tsai, S.-B. Using the DEMATEL model to explore the job satisfaction of research and development professionals in china's photovoltaic cell industry. Renew. Sustain. Energy Rev. 2018, 81, 62-68. [CrossRef]

48. Lee, Y.; Hsiao, Y.; Peng, C.; Tsai, S.; Wu, C.; Chen, Q. Using Mahalanobis-Taguchi system, logistic regression, and neural network method to evaluate purchasing audit quality. Proc. Inst. Mech. Eng. Part B 2014. [CrossRef]

49. Liu, B.; Li, T.; Tsai, S. Low carbon strategy analysis of competing supply chains with different power structures. Sustainability 2017, 9, 835. [CrossRef] 
50. Huang, Z.; Nie, J.; Tsai, S. Dynamic Collection Strategy and Coordination of a Remanufacturing Closed-Loop Supply Chain under Uncertainty. Sustainability 2017, 9, 683. [CrossRef]

51. Qu, Q.; Tsai, S.; Tang, M.; Xu, C.; Dong, W. Marine ecological environment management based on ecological compensation mechanisms. Sustainability 2016, 8, 1267. [CrossRef]

52. Tsai, Sa.; Yu, J.; Ma, L.; Luo, F.; Zhou, J.; Chen, Q.; Xu, L. A study on solving the production process problems of the photovoltaic cell industry. Renew. Sustain. Energy Rev. 2018, 82, 3546-3553. [CrossRef]

53. Chin, T.; Tsai, S.; Fang, K.; Zhu, W.; Yang, D.; Liu, Re.; Tsuei, R.T.C. EO-Performance relationships in reverse internationalization by Chinese Global Startup OEMs: Social networks and strategic flexibility. PLoS ONE 2016, 11, e0162175. [CrossRef] [PubMed]

54. Lee, S.; Su, J.; Tsai, S.; Lu, T.; Dong, W. A comprehensive survey of government auditors' self-efficacy and professional Development for improving audit quality. SpringerPlus 2016, 5. [CrossRef] [PubMed]

55. Lee, Y.; Wang, Y.; Chien, C.; Wu, C.; Lu, S.; Tsai, S.; Dong, W. Applying revised gap analysis model in measuring hotel service quality. SpringerPlus 2016, 5. [CrossRef] [PubMed]

56. Tsai, S.; Zhou, J.; Gao, Y.; Wang, J.; Li, G.; Zheng, Y.; Ren, P.; Xu, W. Combining FMEA with DEMATEL Models to Solve Production Process Problems. PLoS ONE 2017. [CrossRef] [PubMed]

57. Liu, W.; Wei, Q.; Huang, S.; Tsai, S. Doing Good Again? A Multilevel Institutional Perspective on Corporate Environmental Responsibility and Philanthropic Strategy. Int. J. Environ. Res. Public Health 2017, 14, 1283. [CrossRef] [PubMed]

58. Wang, J.; Yang, J.; Chen, Q.; Tsai, S. Collaborative Production Structure of Knowledge Sharing Behavior in Internet Communities. Mob. Inf. Syst. 2016. [CrossRef]

59. Du, P.; Xu, L.; Chen, Q.; Tsai, S. Pricing competition on innovative product between innovator and entrant imitator facing strategic customers. Int. J. Prod. Res. 2016. [CrossRef]

60. Liu, W.; Shi, H.; Zhang, Z.; Tsai, S.; Zhai, Y.; Chen, Q.; Wang, J. The Development Evaluation of Economic Zones in China. Int. J. Environ. Res. Public Health 2018, 15, 56. [CrossRef] [PubMed]

61. Kafouros, M.I. The impact of the internet on R\&D efficiency: Theory and evidence. Technovation 2006, 26, 827-835. [CrossRef]

62. Guo, Z. Optimal decision making for online referral marketing. Decis. Support Syst. 2012, 52, $373-383$. [CrossRef]

63. Floyd, K.; Freling, R.; Alhoqail, S.; Cho, H.Y.; Freling, T. How online product reviews affect retail sales: A meta-analysis. J. Retail. 2014, 90, 217-232. [CrossRef] 